\title{
Zarazne bolesti domaćilh životinja u 18. i 19. stoljeću u banskoj Hrvatskoj
}

\author{
P. Džaja*, S. Sinković, M. Palić, J. Mihalj i K. Severin
}

\section{Sažetak}

$\mathrm{U}$ radu je prikazana pojava i kretanje zaraznih bolesti domaćih životinja u 18. i 19. stoljeću u banskoj Hrvatskoj među kojima dominira goveđa kuga. Navedeni su prvi liječnici koji su prepoznavali zarazne bolesti i radili razudbe domaćih životinja s ciljem utvrđivanja patoanatomskih promjena, odnosno postavljanja dijagnoze. Prikazani su djelatnici koji su suzbijali zarazne bolesti domaćih životinja kao i njihove obveze, odnosno mjere koje su trebali narediti i provesti kao i dužnosti te obveze vlasnika životinja kroz opisani period. U istraživanom razdoblju postavljane su dijagnoze na latinskom i njemačkom jeziku s različitim pojmovima koji su se vjerojatno odnosili na goveđu kugu.

Ključne riječi: zarazne bolesti, stoljeće, domaće životinje, banska Hroatska

\section{Uvod}

Goveđa kuga pojavila se 547. g., 561. g., 570. g. u Galiji i Italiji, a u Irskoj 679. g. Karlo Veliki prekinuo je 791. g. napad na Hune preko Dunava, jer su mu svi konji uginuli od bolesti „equorum lues“, a njegova vojska 801. g. još je jedanput opustošena što se tiče konja. Istočnofranački kralj Arnuf 1896. g. prekinuo je svoje ratne pohode, jer su mu gotovo svi konji uginuli. Zarazne bolesti životinja, to jest goveđa kuga učestalo se javljala pa je zabilježena njezina pojava: 801. g., 810. g., 820. g. 850. g., 870. g., 878. g., 886. g. Bolest se pojavila u Njemačkoj 878. g., a u cijeloj Europi 940. g. i 943. g. Car Henrik IV. 1051. g. morao je prekinuti pohod na Mađare, jer je većina konja podlegla strašnoj epizootiji, a francuski kralj Filip Hrabri 1283. g. imao je 86000 konjanika i morao je stati s napadom na Španjolsku, jer su insekti kod Verone napali ljude i životinje. Goveđa je kuga poharala cijelu Europu 1170.-1172. g., 1223.-1225. g., 1240. g., a Irsku 1321.-1324. g. Velika epizootija boginja pojavila se u Velikoj Britaniji 1275. g. U Italiji je 1301. i 1303. g. uočen veliki pomor konja u Italiji. Goveđa kuga uočena je 1392. g. u Francuskoj, 1394. g. u Švicarskoj, ${ }_{1}^{1}$ 1491. g. u Poljskoj, a 1473. g. nepoznata bolest u Švicarskoj,

1 Lončarić, I. (2001.): Utjecaj srednjeg vijeka na razvoj stočarstva i veterinarstva. Dipl. rad. Vet. fakultet Sveučilišta u Zagrebu.

Dr. sc. Petar DŽAJA*, dr. med. vet., redoviti profesor, (dopisni autor, e-mail: dzaja@vef.hr), Veterinarski fakultet Sveučilišta u Zagrebu, Hrvatska; Sonja SINKOVIĆ, dr. med. vet., Hrvatski veterinarski institut Zagreb, Hrvatska; Magdalena PALIĆ, dr. med. vet., Veterinarski fakultet Sveučilišta u Zagrebu, Hrvatska; Josip MIHALJ, dr. med. vet., Veterinarska ambulanta Soljani, Hrvatska; dr. sc. Krešimir SEVERIN, dr. med. vet., redoviti profesor, Veterinarski fakultet Sveučilišta u Zagrebu, Hrvatska 
1514. g. u Italiji teška zaraza stoke se proširila na Englesku i Francusku, 1675. g. Vjerojatno se bedrenica u Dubrovniku pojavila 1675. g., a raširila se iz Hercegovine. ${ }^{2}$ U Njemačkoj, Francuskoj, Švicarskoj i Poljskoj 1682. g. pojavila se zaraza stoke, ${ }^{3}$ a u našim krajevima ponovne zarazne bolesti stoke javljaju se 1690. g., 1692. g., 1693. g. i 1698. g., a u našim krajevima pojavila se slinavka i šap, 1686. $\mathrm{g}$.

Različite bolesti stoke pojavljuju se u većem broju slučajeva u 1700. g., 1701. g. Fleischhacker iz 1703. g. navodi da ako mesar kupi stoku za klanje nepoznata podrijetla, ili stoku za klanje za koju zna da je bila bolesna oduzet će mu se obrt. ${ }^{4}$ Goveđa kuga 1709. g. pojavljuje se na granici Azije i Europe pa po cijeloj Rusiji, a 1710. g. u Rusiji i Ukrajini pa Poljskoj, Prusiji, Sleziji, Mađarskoj i Austriji, i na koncu Dalmaciji i Italiji. Kuga se pojavila u današnjim prostorima Hrvatske 1710. g. ${ }^{5}$, a 1711. g. pojavila u središnjoj Hrvatskoj. ${ }^{6,7}$ Goveđa kuga harala je po Srednjoj Europi 1711. g. kada se proširila iz Mađarske, a te godine donesen je Austrijski edikt. U 1712. g. preko Tirola bolest se proširila u Švicarsku, Francusku, Belgiju i Nizozemsku kada je uginulo 200000 grla. U Engleskoj je 1714. g. uginulo 74000 grla. Kuga se 1714 . g. pojavila u današnjim prostorima Hrvatske. Kod nas prvi službeni podatak o zarazama potječe iz 1714.

2 Brozović, L. (1959.): Prilog povijesti Veterinarstva u Hrvatskoj. Narodna tiskara Varaždin.

3 Homan, D. (1941.): Hrvatski dnevnik 26.1. Prva Veterinarska knjiga na našem jeziku u Hrvatczkom orszagu.

4 Lukačević, J. (1984.): Stočne zarazne bolesti u Hrvatskoj u 18. stoljeću. I. Podaci o propisima o suzbijanju zaraza za razdoblje od 1700.1775. g. s osvrtom na Linzabauerov "Codex sanitario" Vet. arhiv 54, 51-61.

5 Lukačević, J. (1986.): Stočne zarazne bolesti u Hrvatskoj u 18. stoljeću. IV. O učestalosti stočnih zaraza u tijeku 1700.-1775. godine. Vet. arhiv 56, 99-108.

6 Vučevac Bajt, V. (2012.): Povijest veterinarstva. Zagreb.

7 Brozović-rukopis g. kada Sabor kraljevine Dalmacije, Hrvatske i Slavonije zabranjuje izvoz stoke iz Hrvatske zbog nestašice mesa poslije učestalosti lues pecoris et animalium. ${ }^{8}$ Kuga se ponovno pojavljuje 1724. g. u Poljskoj. Karlo VI. 1727. g. naređuje uz opći popis stanovništva i popis stoke.

Godine 1730. bilo je propisano kada u jednom ili više dvorišta ugine veći broj životinja odjednom, zaraza se obvezno morala prijaviti mjesnim vlastima koje izvješćuju višu vlast koja je propisivala zatvor zaraženog dvorišta, zabranu kretanja ljudi i životinja iz zaraženog kruga i slanje na zaraženo područje veterinarsko medicinske stručnjake i dr. Kod pojave Vieh-Seuche treba odvojiti zdravu od bolesne stoke, a životinje oboljele od ove bolesti moraju se zakopati zajedno s kožom i to na odvojenu mjestu udaljenom od stanovanja, a ljudi koji se brinu o tim životinjama ne smiju biti u društvu s drugim ljudima. U propisu iz 1730. g. koji nosi naziv Vieh-Ordnung dan je i popis lijekova koji se imaju upotrebljavati pri liječenju ove bolesti. ${ }^{9}$ Karlo VI. 1731. g. izdaje Naredbu prema kojoj se prema Stajerskoj trebaju poduzeti sve preventivne mjere zbog sprječavanja širenja opasne zaraze.

Bolest goveđa kuga 1731. g. pojavila se na području sjeverne $\operatorname{Hrvatske}^{10}$, a zbog učestale pojave navedene bolesti Sabor 23. 4. 1731. g. daje nalog nižim organima da se sve uginule životinje zakopaju zajedno s kožom koje su uginule od Lues animalium uz obvezan nadzor tog posla. Na sjednici Sabora 26. 11. 1735. g. zaklju-

8 Lukačević, J. (1986.): Stočne zarazne bolesti u Hrvatskoj u 18. stoljeću. IV. O učestalosti stočnih zaraza u tijeku 1700.-1775. godine. Vet. arhiv 56, 99-108.

9 Lukačević, J. (1984.): Stočne zarazne bolesti u Hrvatskoj u 18. stoljeću. I. Podaci o propisima o suzbijanju zaraza za razdoblje od 1700 .1775. g. s osvrtom na Linzabauerov „Codex sanitario" Vet. arhiv 54, 51-61.

10 Vučevac Bajt, V. (2012.): Povijest veterinarstva. Zagreb. 
čeno je budući da Lues animalium bjesni cijelim kraljevstvom sve životinje koje uginu od ove bolesti trebalo je zakopati s kožom, a za oboljele životinje dobivao se lijek od podbana za njihovo izlječenje. ${ }^{11}$ Ove 1735. g. zabilježen je veliki pomor stoke. ${ }^{12} \mathrm{U}$ Podravini dijagnosticirana je 1836. g. bedrenica, a veći pomor stoke u cijeloj današnjoj RH 1737. g. Goveđa kuga pojavila se 1740. g. u sjevernoj Hrvatskoj, a 1743.-1744. g. njena epidemija zabilježena je u Kostajnici i u središnjoj Hrvatskoj. Sabor je 1. 12. 1740. g. izvijestio caricu Mariju Tereziju da je hrvatski narod jako osiromašio zbog dugogodišnjeg trajanja Lues animaliuma. Zabilježeno je da su stočari iz Slovenije 1743. g. bacali uginulu marvu u Dravu zbog čega se bolest pojavila u Varaždinskoj županiji. Iste godine bolest bjesni u Križevačkoj županiji. 13,14 Nepoznati pisac 1743. g. piše da su konji u Hrvatskoj mršavi, maleni i neugledni, ali zato jaki i ustrajni, tako da i najmanji i najneugledniji konji jakoga čovjeka lahko i voljko nose. Trče brzo bez obzira na zapreke. ${ }^{15} \mathrm{U}$ Hrvatskoj goveđa kuga utvrđena je 1743. g. Ponovno se pojavljuje 1744.-1745. g., kada je zabilježena njezina epidemija u Sisku-(Krčelić) kao i 1746. g., 1748. g. goveđa kuga dijagnosticirana je u sjevernoj Hrvatskoj, a i u ostalim dijelovima zemlje 1749. g. ${ }^{16}$ Liječnik Michael

11 Lukačević, J. (1984.): Stočne zarazne bolesti u Hrvatskoj u 18. stoljeću. I. Podaci o propisima o suzbijanju zaraza za razdoblje od 1700.1775. g. s osvrtom na Linzabauerov „Codex sanitario" Vet. arhiv 54, 51-61.

12 Vučevac, V. (1979.): Povijest suzbijanja i sprječavanja stočnih zaraza u Hrvatskoj. Vet. arhiv 49, 299-307.

13 Lukačević, J. (1986.): Stočne zarazne bolesti u Hrvatskoj u 18. stoljeću. IV. O učestalosti stočnih zaraza u tijeku 1700.-1775. godine. Vet. arhiv 56, 99-108.

14 Brozović- rukopis

15 Vučevac-Bajt, V. (1979.): Povijest suzbijanja i sprječavanja stočnih zaraza u Hrvatskoj. Vet. arhiv 49, 299-307.

16 Lukačević, J. (1986.): Stočne zarazne bolesti u Hrvatskoj u 18. stoljeću. IV. O učestalosti
Hinterholczer (vojni kirurg) 1746. g. moli isplatu plaće i mjesto kirurga u Zagrebu ili u Kostajnici, a 1747. g. traži da mu se nabave instrumenti. On 1755. g. podnosi molbu da mu se povisi plaća. Goveđa kuga se širi prema Podravini 5. 8. 1748. g., a Sabor dopušta promet stokom samo ako njezini vlasnici imaju „passus.“ Lues pecoris 1750. g. raširen je u Baranji i Srijemskoj županiji zbog čega Sabor šalje komisiju na teren koja je trebala povremeno izvještavati zamjenika bana o zaraženim mjestima. Sabor iste 1750. g. traži od srijemske županije da pošalje svoju komisiju da se utvrdi gdje su postavljene straže da se spriječi širenje bolesti Lues pecoris iz Baranje i Bačke. Te 1750. g. bolest je dijagnosticirana u sjevernoj Hrvatskoj, a u drugim dijelovima Hrvatske 1751. g., ${ }^{17}$ 1755. g., ${ }^{18} 1756$. g. ${ }^{19} 1757$. g. i 1958. kao i 1763. g., 1764. g. ${ }^{20}$ i 1767.-1779. g.

Carica Marija Terezija 1753. g. donosi ponovno propise o suzbijanju stočnih zaraza po kojima je gazda kuće gdje se bolest pojavila morao to prijaviti gazdi sela, a on dalje na višu vlast. Zaraženo mjesto je trebalo vidljivo označiti i ono se zabranjivalo za promet stoke. U literaturi nalazimo da liječnik De Degoüy -1754. i 1758. g. od Sabora oba puta dobiva na svoje traženje povišicu plaće. ${ }^{21}$ Iz Zapisnika Sabora od 17. 11. 1755. g. vidljivo je da je u križevačkoj i zagrebačkoj županiji učestala Lues animalium zbog čega se naređuje da zagrebački i križevački podžupa-

stočnih zaraza u tijeku 1700.-1775. godine. Vet. arhiv 56, 99-108.

17 Vučevac Bajt, V. (2012.): Povijest veterinarstva. Zagreb.

18 Vučevac Bajt, V. (2012.): Povijest veterinarstva. Zagreb.

19 Vučevac Bajt,V. (2012.): Povijest veterinarstva. Zagreb.

20 Vučevac Bajt, V. (2012.): Povijest veterinarstva. Zagreb.

21 Lukačević, J. (1984.): Stočne zarazne bolesti u Hrvatskoj u 18. stoljeću. II. Djelatnost liječnika u suzbijanju zaraza u razdoblju od 1700. do 1775. godine. Vet. arhiv 54, 223-231. 
ni međusobno dogovore da se još slobodna mjesta čuvaju stražom. ${ }^{22}$ Ove godine uočen je veći pomor stoke kao i slijedeće 1756. godine. Bolest se 1756. g. pojavila u Stenjevcu, Oroslavlju, Donjoj Stubici, Gornjoj Stubici, Bistri i dr. mjestima. Do 1756. g. propise koje je donijela carska vlada slani su u Sabor na usvajanje, koji ih je onda slao preko županije na teren, a od 1756.-1767. g. nije više bilo tako. Od ove 1756. g. ranarnici su uz liječenje ljudi trebaju liječiti i stoku. ${ }^{23}$ Propisi „Remedia medica tam praeservantiva quiam curativa contra luem animalia" tiskani su 1756. g. na njemačkom jeziku i poslani su u Sabor. Između ostaloga navodi se dosta lijekova koji se koriste $\mathrm{u}$ preventivne i kurativne svrhe. Navode se stočne zaraze koje nisu bile navedene 1730. g. i to: malus contagionis, kašalj, scabies, dysenteriacum, ulcera, tubera, i vjerojatno bedrenica. Carskim reskriptom iz 1756. g. mijenja se nešto $u$ Vieh-Ordnung iz 1730. g. s tim da se dopušta skidanje kože od uginulih goveda od lues pecoris i dati na javnu uporabu.

U području Bjelovara 1757. g dijagnosticirana je bolest lues pecoris. Od bolesti je 1756.-1757. g. u Zagrebačkoj županiji uginulo 11 životinja. Nalazimo pisano izvješće iz Drenovaca 1757. g. da je stoka u Velikom Gradecu zdrava osim jednog uginulog teleta od Lues mali Temporis et Stabuli. Iste godine spominje se i drugi liječnik koji je sudjelovao u suzbijanju zaraznih bolesti životinja De Bianchi koji je u spisima pronađen 1757. g u vezi s njegovom djelatnošću u humanoj medicini. ${ }^{24,25}$

22 Lukačević, J. (1986.): Stočne zarazne bolesti u Hrvatskoj u 18. stoljeću. IV. O učestalosti stočnih zaraza u tijeku 1700.-1775. godine. Vet. arhiv 56, 99-108.

23 Lukačević, J. (1991.): Neki podaci o veterinarsko-medicinskoj djelatnosti na širem i užem području Bjelovarske općine u 18. i 19. st. Vet. stn. 22, 229-231.

24 Lukačević, J. (1984.): Stočne zarazne bolesti u Hrvatskoj u 18. stoljeću. II. Djelatnost liječnika u suzbijanju zaraza u razdoblju od 1700. do 1775. godine. Vet. arhiv 54, 223-231.

25 Lukačević, J. (1984.): Stočne zarazne bolesti u
U Turopolju kod Zagreba 1758. g. vladala je stočna zaraza (contagion). U izvješću se navodi da je podnijeta prijava sucu da zabrani kupovinu takve stoke mesarima iz Dalmacije i Slavonije. ${ }^{26}$

U Izvješću iz 1758. g. o zarazi u Turopolju zabranjuje se krijumčarenje mesa noću od uginule stoke $u$ Zagreb te naređuje zakapanje lešina da psi ne prenose bolest. Zagrebački magistrat ga nije podržao pa on traži potporu bana. Goveđa bolest pojavila se 1758. g. u Turopolju, a 1760. g. u Brodu. Carica 1759. g. zabranjuje održavanje sajmova gdje stoga ugiba od Luesa, a dopušta izvoz volova u Veneciju. Bolest je 1761. g. raširena u Zagrebačkoj županiji zbog čega se traži zatvaranje sajmova. Bolest se pojavila 1763. g. u Jaski, Rečici, Donjoj Kupčini, Draganjiću, Šišlaviću, Karlovcu, Senkovcu, Laduču, Sv. Nedjelji, Kerestincu i dr. ${ }^{2728}$

Ove godine 1.6.1763. g. carica Marija Terezija izdaje naredbu Medico scopo luem pecorum curandi in regnum ducendi, to jest da liječnici imaju obvezu osim liječenja ljudi liječiti i stoku (verum etiam infirmo medensi pecor). Bianchi (zagrebački fizik primarijus) 1763. g dobiva nalog da obavi uvid u Lues pecoris koji već 8 godina bjesni u okolici Zagreba. Opisan je patoanatomski nalaz u jednog vola / Vesica felea bili plena, et in duplo naturalis major visebat/ oko žučnih kanala su male kameničaste tvorbe veličine boba. O njemu nema drugih podataka. Isto tako, iz 1763. g. nalazimo podatke o Benedettiju u

Hrvatskoj u 18. stoljeću. II. Djelatnost liječnika u suzbijanju zaraza u razdoblju od 1700. do 1775. godine. Vet. arhiv 54, 223-231.

26 Lukačević, J. (1986.): O izvješćima liječnika koji su u 18. stoljeću suzbijali stočne zarazne bolesti u Hrvatskoj. Vet. stn. 17, 35-38.

27 Lukačević, J. (1986.): Stočne zarazne bolesti u Hrvatskoj u 18. stoljeću. IV. O učestalosti stočnih zaraza u tijeku 1700.-1775. godine. Vet. arhiv 56, 99-108.

28 Lukačević, J. (1991.): Neki podaci o veterinarsko-medicinskoj djelatnosti na širem i užem području Bjelovarske općine u 18. i 19. st. Vet. stn. 22, 229-231. 
prvom dokumentu se navodi da je Sabor primio isprave od per medicum Benedetti doctoratu te mu na temelju njegove doktorske diplome dozvoljava liječničku praksu.

U drugom dokumentu se navodi da je Benedetti suzbijao Lues pecoris 1763. g. u Zagrebačkoj županiji te je u Draganiću obavio sekciju jednog junca u čijim je jetrima našao mnogo crva. ${ }^{29}$ Isto tako 1763. g. šalje se izvješće Mariji Tereziji da se lues pecoris pojavio u blizini grada Varaždina, bolesne životinje obuzme strah, slabije jedu i piju teško dišu. U jedne privedene životinje klanju vidljivo je da je pun žučni mjehur te misli da je u pitanju i upala pluća. On daje mišljenje o uzroku stalne prisutnosti lues animalium-a u Hrvatskoj kada navodi da je jedan od uzroka ne zakapanje leševa. Isti misli da se zaraza širi uvozom koža iz Turske. ${ }^{30}$ Bolest je 1764. g. utvrđena u Zagrebačkoj županiji. Regolamento (kodeks) donesen je 1764., a 11.10. 1766. g. gradski senator dopušta Matiji Ivanusu iz Sela Prosinca na Sutli da smije za potrebe gradskog mesara dovesti 10 goveda iz Erdedijevih Novih dvora na Sutli. Iz 1766. g. imamo podatak iz Ozlja gdje ban u pismu upozorava da se lešine zaraženih životinja moraju zakopati i tako sprječava širenje bolesti. Kraljica reskriptom piše 7. 8. 1767. g. banu Hrvatske da milostivo dopušta skidanje koža od životinja koje su uginule od lues animalium, jer je u Francuskoj, Nizozemskoj i Hrvatskoj utvrđeno da se ona njima ne širi, a njihovim korištenjem smanjuju se štete. Iste godine 1767. g. osnovano je Vijeće kraljevstva Hrvatske Slavonije i Dalmacije koje je moralo oglasiti naredbe kraljice i zapovjediti

29 Lukačević, J. (1984.): Stočne zarazne bolesti u Hrvatskoj u 18. stoljeću. II. Djelatnost liječnika u suzbijanju zaraza u razdoblju od 1700. do 1775. godine. Vet. arhiv 54, 223-231.

30 Lukačević, J. (1984.): Stočne zarazne bolesti u Hrvatskoj u 18. stoljeću. II. Djelatnost liječnika u suzbijanju zaraza u razdoblju od 1700. do 1775. godine. Vet. arhiv 54, 223-231. ih županijama, od kada se propisi koji su doneseni u carskoj kancelariji u Beču daju putem Vijeća na izvršenje carskim mandatom. Paulus Adami 1767. g. je suzbijao bolest u Hrvatskoj (Orban) iako podataka o tome Lukačević nije našao. Stočne bolesti javljaju se 1767. g., 1770. g., 1771. g. goveđa kuga potvrđena je u Varaždinu, 1786. g. od goveđe kuge u 4 Đurđevačke pukovnije uginulo je 246 goveda, a bolest se pojavljuje u cijeloj Europi 1740. g. i 1750. g. Na posjedu Hrašćina (Varaždinska županija), Budinščini 1767. g. u 3 sela uginulo je 20 grla. U Konjščini je 1768. g. u 8 sela oboljelo od Lues animalium 57 od čega je uginulo 37 komada stoke. Na imanju grofa Joanna Pattachica i u Donjem Zagorju uginulo je po 12 goveda. De Gracy (liječnik Varaždinske županije) 1769. g. prikupio je podatke na terenu o bolesnim životinjama gdje utvrđuje krvarenje po prsima i trbušnim organima, ikterus, obstrukciju i povećani žučni mjehur ${ }^{31}$ te postavlja dijagnozu kod jednog vola Sporadicus morbi. ${ }^{32}$ Od lues pacoris u 1769. g. u 12 sela uginulo je 416 goveda. Vijeće 1769. g. dostavlja svim županijama tablu kako treba postupiti u slučaju pojave Lues animalium-a i po obavljenom poslu nju ispuniti i njemu poslati. Treba navesti kad se Malus pojavio, kada je stigla komisija radi suzbijanja zaraze, kada i gdje je postavljena straža da se zaraza ne bi širila, koji su lijekovi davani preventivno, a koji kurativno.

Propise donesene 2. 1. 1770. g. pod nazivom "Generale Normativu min Re Sanitatis" objavila je carica Marija Terezija, a na latinskom jeziku tiskani su 17. 9. 1770. g. Od 9 članaka $(3,8,2$,

31 Lukačević, J. (1984.): Stočne zarazne bolesti u Hrvatskoj u 18. stoljeću. II. Djelatnost liječnika u suzbijanju zaraza u razdoblju od 1700. do 1775. godine. Vet. arhiv 54, 223-231.

32 Lukačević, J. (1991.): Neki podaci o veterinarsko-medicinskoj djelatnosti na širem i užem području Bjelovarske općine u 18. i 19 st. Vet. stn. 22, 229-231. 
5, 9) navode zadatke fizika u suzbijanju stočnih zaraza, a u dva članka suzbijanje zaraza u ljudi i životinja. Čl. 9 obuhvaća njegove dužnosti isključivo iz domene zaraznih bolesti životinja. On navodi ako se pojavi zaraženo životinjsko zlo, prva je dužnost fizikova da istraži uzrok nastala zla, da istraži kako treba liječiti stoku te da se to provede na teritoriju cijele naše kraljevine i carevine. ${ }^{33} \mathrm{U}$ poznatim zdravstvenim propisima navodi se da je liječnicima podjednaka dužnost da suzbijaju zarazu u ljudi tako i u životinja. ${ }^{34}$ Podatci o zarazama do 1770. g. odnose se samo na goveda, a prvi put se 1771 . g. spominju svinje, a 1775 . g. konji i mule. Za zarazne bolesti rabe se pojmovi Lues pecoris, lues animalium, lues mali, Contagion, a na njemačkom Viehseuche i dr. ${ }^{35}$ Iste godine zabilježen je veći pomor stoke. Carica Marija Terezija 1771. g. objavila ponovno nove propise o suzbijanju stočnih zaraza. Oni su skup propis od 1730. g. do 1771. g. Sačuvan je dio zapisnika komisije Požeške županije od 2. 2. 1771. g. koja je provodila suzbijanje zaraznih bolesti te županije. Za sprječavanje pojave i širenja Luesa imaju se imenovati sanitarne komisije i inspektori (komesari). Kad se pojavio prvi slučaj isti se trebao prijaviti komesaru. Ako se lues nije ugušio pri prvoj pojavi već se raširi, o tome se izvještavao kapetan okruga ili podžupan županije od okružnog sanitetskog komesara koji suzbija zarazu, komesaru se trebao pridruži fizik koji je trebao pomagati savjetom prema zakonu.

33 Lukačević, J. (1985.): Podaci o propisima što se odnose na suzbijanje stočnih zaraza iz 1772. i 1816. godine s osvrtom na podatke iz dotadašnjih propisa. Vet. stn. 16, 57-59.

34 Lukačević, J. (1984.): Stočne zarazne bolesti u Hrvatskoj u 18. stoljeću. II. Djelatnost liječnika u suzbijanju zaraza u razdoblju od 1700. do 1775. godine. Vet. arhiv 54, 223-231.

35 Lukačević, J. (1986.): Stočne zarazne bolesti u Hrvatskoj u 18. stoljeću. IV. O učestalosti stočnih zaraza u tijeku 1700.-1775. godine. Vet. arhiv 56, 99-108.
Kod pojave luesa liječnik je dužan dati lijekove. U 1771. g. Varaždinska županija šalje izvješće o Morbi bovum grassantis. Na sjednici Sanitarne komisije Vijeća 1771. g. Hinterholzer daje svoje mišljene o širenju Luesa pecorisa navodeći da je do bolesti došlo zbog skidanja koža s uginulih životinja. Dana 14. 10. 1771. g. javlja regimenta iz Gradiške grofu Jankoviću u Pakrac da je na svim mjestima gdje bjesni Viehseuche postavljena crna tabla. ${ }^{36}$

U propisima koji su stupili na snagu 1771. g. u Hrvatskoj dati su zadatci liječnicima kod pojave zarazne bolesti životinja. ${ }^{37} \mathrm{O}$ suzbijanju stočne zaraze 1771. g. brine se kapetan čete ili podžupan županije ako je zaraza izbila na području županije. Joannes Baptiste de Benedictus (medicus ordinarius Comitatus Zagrebiensis) 1771. g. je na imanju grofa Patačića u Zelini obavio razudbu utamanjena vola te je našao živih crvi u jetrima. Drugim nalazom iz 1771. g. je utvrdio Morbus Bovis Grassantis u uginulih životinja Zagrebačke županije u Kraljevcu. ${ }^{38}$ Ove godine je kod grofa Patačića u Zelini utvrdio da bjesni Morbus bovis kada su životinje imale smanjen apetit, a razudbom priklanog vola utvrdio je Cistifelea bili aquosa erat plenissima. U drugih razuđenih životinja utvrdio je Echinos, gdje je omazus natrpan tvrdim suhim sadržajem, žučni mjehur pun je crva, a pluća su u nekim slučajevima upaljena. Nalazimo zapis da je 1771. g. da je Joannes Catinelli u Požegi u komisiji

36 Lukačević, J. (1984.): Stočne zarazne bolesti u Hrvatskoj u 18. stoljeću. I. Podaci o propisima o suzbijanju zaraza za razdoblje od 1700.1775. g. s osvrtom na Linzabauerov „Codex sanitario" Vet. arhiv 54, 51-61.

37 Lukačević, J. (1984.): Stočne zarazne bolesti u Hrvatskoj u 18. stoljeću. II. Djelatnost liječnika u suzbijanju zaraza u razdoblju od 1700. do 1775. godine. Vet. arhiv 54, 223-231.

38 Lukačević, J. (1991.): Neki podaci o veterinarsko-medicinskoj djelatnosti na širem i užem području Bjelovarske općine u 18. i 19. st. Vet. stn. 22, 229-231. 
za suzbijanje bolesti, ${ }^{39}$ a vidi se da je i 1771. g. bio veći pomor stoke. Pomoćno osoblje u suzbijanju zarazni bolesti bili su: kovači (faber), komesari, inspektori i drugi. Čini se da su njemu pripadali i excoriatores, jer u pismu Marija Terezija 28. 10. 1771. g. Hrvatskom Kraljevskom vijeću navodi se da su excoriatores skidali kožu s lešina uginulih od lues pecoris i raširili bolest navodeći da je to krimen. Sanitarna komisija 26. 10. 1771. g. pri Hrv. Kraljevskom vijeću raspravljala je iz kojih će se sredstava platiti excoriatores (mesari koji skidaju kožu, gulikoža). Nema podataka o naobrazbi fabera, podžupana te velikog i malog plemićkog suca. Administrativno osoblje bili su: podžupani (vice comes), veliki i mali plemićki suci (judices nobilium et vice judices nobilium) i drugi. ${ }^{40}$

Propis iz 1772. g. pisan je rukom na 6 stranica, a na njegovoj poleđini piše latinski Uputa na narodnom jeziku za povjerenike o Luesu. U prvom članku se navodi da u svakom kotaru treba izabrati jednog komesara (povjerenika) čija je bila zadaća da se brine o svakoj kući svojega kotara. Ako je trebalo mogao je zatražiti pomoć inspektora. U drugom čl. se navodi da inspektor treba u svakom selu izabrati jednog stražara jer on sam ne može nadzirati svaku kuću. U 5. članku navodi se da je potrebno same gospodare naučiti da ne zakapaju lešine dok ih inspektor ne pregleda. Sedmi članak ako bi se prilikom pregledavanja stoke naišlo na kugu, inspektor je zabranjivao miješanje bolesnih sa zdravim životinjama te je navedeno kako treba postupati "zdrava kuća" da se bolest ne pojavi. U 8. članku se govori kako treba postupati ako se bolest ne uspije odmah

39 Lukačević, J. (1984.): Stočne zarazne bolesti u Hrvatskoj u 18. stoljeću. II. Djelatnost liječnika u suzbijanju zaraza u razdoblju od 1700. do 1775. godine. Vet. arhiv 54, 223-231.

40 Lukačević, J. (1991.): Neki podaci o veterinarsko-medicinskoj djelatnosti na širem i užem području Bjelovarske općine u 18. i 19. st. Vet. stn. 22, 229-231. $\mathrm{u}$ početku suzbiti oni gospodari koji su se pridržavali naređenih mjera koliko toliko nadoknađivala im se šteta. Ovo je najstariji propis na narodnom jeziku. U propisima se upotrebljavaju nazivi kuga, beteg i što se vjerojatno odnosilo na goveđu kugu. ${ }^{41}$ Iste godine u Brodskoj županiji i gradiškoj pukovniji ustanovljen je Lues pecoris.

Ugarsko Namjesničko vijeće 1774. g. naredilo je svim svojim županijama da svakih 6 mjeseci dostavljaju podatke prema tabeli De lue pecorum i to podatke oboljelih, ozdravilih i uginulih po mjesecima. Od 1775. g. carica je mogla neposredno izdavati zapovijedi narodu preko županija, a osnutkom županija oduzela je dosta poslova Saboru. ${ }^{42}$ Seuche se 1775 . g. pojavljuje na konjima i mulama u 4 mjesta in teritorio comercieli (na dijelu Hrvatske krajine koji je bio $\mathrm{u}$ posjedu Frankopana prije pogibije Krste Frankopana). Zaraza lues pecoris se pojavila u 13 mjesta u Hrvatskoj provinciji. Godine 1775. g. i 1780. g. u Istri se pojavila pleuropneumonija goveda, a 1785. g. pojavila se bedrenica u Hrvatskoj na gospodarstvu Oršić. Joanes Baptista Lalangue (Var. Fizik) u Biškupovcu kod Varaždina 1778. g. na obdukciji jedne krave našao je tvrdu jetru, a žučni mjehur bio je povećani pun žuči te je postavljena dijagnoza Lues pecoris. Od 1779.-1780. g. u Istri se pojavila plućna zaraza. Goveđa kuga pojavila se 1781. g., a 1783. g u Botovu, i Križevačkoj županiji. Bedrenica se pojavila 1785. g. ${ }^{43}$ Županije se ukidaju 18. 3. 1785. g., a cijela Ugarska

41 Lukačević, J. (1985.): Podaci o propisima što se odnose na suzbijanje stočnih zaraza iz 1772. i 1816. godine s osvrtom na podatke iz dotadašnjih propisa. Vet. stn. 16, 57-59.

42 Lukačević, J. (1984.). Stočne zarazne bolesti u Hrvatskoj u 18. stoljeću. I. Podaci o propisima o suzbijanju zaraza za razdoblje od 1700.1775. g. s osvrtom na Linzabauerov „Codex sanitario" Vet. arhiv 54, 51-61.

43 Vučevac, V. (1979.): Povijest suzbijanja i sprječavanja stočnih zaraza u Hrvatskoj. Vet. arhiv 49, 299-307. 
i Hrvatska podijeljene su na 9 okružja. ${ }^{44}$ Mauritius Faby (ord. Physicus) 1786. g. dijagonosticirao je Pecorum morbis u jedne krave u Hrv. Zagorju. ${ }^{45}$ Aliquis animalium morbus pojavio se 1786. g. u Zagrebačkoj županiji, a lues pecoris u 4 čete Đurđevačke pukovnije gdje je uginulo 246 goveda. U zagrebačkoj županiji u 7 veleposjeda ukupno je oboljelo 102 goveda od kojih je 94 uginulo. Čini se da je bila raširena metiljavost koja je bila raširena još u Varaždinskoj županiji i Međumurju. U Varaždinskoj županiji uginulo je 21 grlo, a u Međimurju oko 2000 grla goveda.

Naredbom od 3. 1. 1787. odlučeno je da ne može biti namješten na županiji ni na gradskom magistratu ni jedan Heilartz ni Wundartz koji nije slušao predavanje (an der hohen Schule zu Pestt) i na njoj dobio dobru ocjenu. Pod brojem $134 \mathrm{u}$ Zagrebu je opisana živoderna kuća sa sobom, kuhinjom i komorom u ruševnom stanju još 1788. g. ${ }^{46 ; 47} \mathrm{Na}$ popisu od 21. 9. 1790. g. od 42 kandidata koji su položili ispit in arte veterinariaie je ime i Stephanus Mihalovics koji bi mogao biti iz Hrvatske, a epizotija Viehseuche je 1790. g. harala u Zagrebačkoji u 1 mjestu požeške županije. Od lues animalis 1791. g. uginulo je u Križevačkoj županiji 100 goveda, a zaraza se u Varaždinskoj županiji proširila na Biškupec te se 1792. g. pojavljuju pojedinačni slučajevi bolesti. Lues animalis 1793. g. uočen je u Samoboru i Bregani, a 1795. g. u Zagrebačkoj županiji od ove bolesti uginulo 11 goveda. Zbog pojave bolesti 1796. g. u Zagrebačkoj županiji

44 Lukačević, J. (1989.): Stočne zarazne bolesti u Hrvatskoj u 18 stoljeću. VI. O učestalosti stočnih zaraza i tijeku 1776. do 1779. godine. Vet. arhiv 59, 41-48.

45 Lukačević, J. (1991.): Neki podaci o veterinarsko-medicinskoj djelatnosti na širem i užem području Bjelovarske općine u 18. i 19. st. Vet. stn. 22, 229-231.

46 Lassovski, E. (xxxx): Stari i Novi Zagreb.

47 Vučevac, V. (1979.): Povijest suzbijanja i sprječavanja stočnih zaraza u Hrvatskoj. Vet. arhiv 49, 299-307. zabranjena je trgovina stokom. Rabies 1797. g. bjesni na imanju Topolovec, a od ugriza bijesnog vuka umrlo je 3 ljudi i uginulo je 17 goveda i 15 svinja. Određena je karantena od 40 dana za ugrizene kao za ne ugrizene koje su bile s ugrizenim životinjama. Bjesni i animalium infirmitatis 1798.-1799. g. u cijeloj županiji kao i u Varaždinskoj županiji 1800. g. „bjesnila“ je epizotica grassantur od čega je oboljelo 516 grla od čega je uginulo $229 .{ }^{48}$

Boginje ovaca pojavljuju se 1807 . g. u Vlaško-ilirskoj pukovniji, a ove godine pokušano je bezuspješno cijepljenje. Slijedeće 1808. g. donijeta je Naredba o postupku s lutajućom stokom. U Vlaškoilirskoj pukovniji je 1813. g. uginulo je 20 442 ovce od metiljavosti, a od golubnjačke mušice uginulo je 10000 komada stoke. ${ }^{49}$ Goveđa kuga poharala je Hrvatsku 1814. g., a 1863. g. Hrvatsku i Slavoniju. Naredba o postupku prilikom bjesnoće donijeta je 1820. g. Carski reskript donesen je 8. 5. 1829. g. ${ }^{50}$

Godine 1816. tiskan je na latinskom jeziku i u njima se pojedinačno navode zarazne bolesti. U čl. 10 se navodi da treba $\mathrm{u}$ preventivne svrhe upotrebljavati sal communis $i$ nitrum. U čl. 11 navodi se Lues omasi (goveđa kuga) ne samo što u životinja tvori predispoziciju za upalno truljenje nego i truje te uzrokuje neplodnost. U čl. 12 navode se vrlo priljepčive, opasne zarazne bolesti koje su raširene na velikim prostorima: Lues omasi $i$ Variola Ovium, a u čl. 13 navode se zaraze koje su raširene na velikim prostranstvima, a ne šire se dodirom: Lues Oris, Lues pedum seu

48 Lukačević, J. (1989.): Stočne zarazne bolesti u Hrvatskoj u 18 stoljeću. VI. O učestalosti stočnih zaraza i tijeku 1776. do 1779. godine. Vet. arhiv 59, 41-48.

49 Benčević, Z. (1929.): Povijest veterinarstva Hrvatske i Slavonije od 1800.-1850. te bivše Vojne Krajine do njena ukinuća. Vet. fakultet Zagreb, Disertacija.

50 Vučevac, V. (1979.): Povijest suzbijanja i sprječavanja stočnih zaraza u Hrvatskoj. Vet. arhiv 49, 299-307. 
Tabela 1. Učestalost zaraze (Lues Mali) u tijeku 1700. do 1771. godine prema županijama, odnosno u Hrvatskoj i slavonskoj krajini prema Lukačević, J. (1986.): Stočne zarazne bolesti u Hrvatskoj u 18. stoljeću. IV. 0 učestalosti stočnih zaraza u tijeku 1700.-1775. godine. Vet. arhiv 56, 99-108.

\begin{tabular}{|l|c|c|}
\hline $\begin{array}{l}\text { Županije/ } \\
\text { Krajina }\end{array}$ & $\begin{array}{c}\text { Godina/Br. } \\
\text { mjesta }\end{array}$ & $\begin{array}{c}\text { Br. uginulih } \\
\text { goveda }\end{array}$ \\
\hline Požeška & $1770 .-0$ & 32 \\
$1771 .-7$ & 334 \\
\hline Virovitička & $1770 .-29$ & 4801 \\
$1771 .-21$ & 2390 \\
\hline Srijemska & $1770 .-8$ & 43 \\
\hline Križevačka & $1771 .-4$ & 570 \\
\hline Varaždinska & $1770 .-0$ & 0 \\
\hline Zagrebačka & $1771 .-3$ & 165 \\
\hline Hrv.-slav. & $1771 .-6$ & 103 \\
\hline krajina & $1771 .-12$ & 95 \\
\hline Ukupno & $931 .-0$ & 95 \\
\hline
\end{tabular}

ungularum, Aphte linguae, lues pulmonis, lienitis, hepatitis, fasciola hepatica, angina setigerorum. U čl. 14 navedene su zarazne bolesti koje se šire od dodirom, ali kad se pojave ne šire se brzo: Coryxa seu morbus pituitois Equorum, Scabies ovium, Equorum et aliorum animalium, rabies canina seu hydrophobia, ${ }^{51}$ Maleus se pojavio 1833. g. na vlastelinstvu Osekovo i Strušec kod Kutine. Bedrenica se pojavila 1836. g. u Podravini, ${ }^{52,53}$ a od te 1836. g. u Varaždinu živoderi imaju svoju zastavu na kojoj je bila slika konja s prebijenom nogom.

U carskim reskriptima od 11.11. 1837. g. date su upute vlastima i krajišnicima te su opisani znaci bolesti i obrambene mjere od zaraznih bolesti. Spominju se bedrenica, ovčje boginje, slinavka i šap, šuga i vrbanac. Zakonskim člankom 9. iz 1840. g. za područje cijele civilne Hrvatske zabranjuje se na skupnu pašu goniti stoka oboljela od zarazne bolesti. Slinavka i šap se pojavila 1843. g. na području Banske, Slunjske i Križevačke pukovnije. Naredba o pregledu životinje prije klanja i mesa namijenjenog javnoj potrošnji donesena je 13. 12. 1846. g. B 5770, a za području civilne Hrvatske Naredba kr. Hrvatskeslavonske-dalmatinske zemaljske vlade

51 Lukačević, J. (1985.): Podaci o propisima što se odnose na suzbijanje stočnih zaraza iz 1772. i 1816. godine s osvrtom na podatke iz dotadašnjih propisa. Vet. stn. 16, 57-59.

52 Brozović- rukopis

53 Vučevac, V. (1979.): Povijest suzbijanja i sprječavanja stočnih zaraza u Hrvatskoj. Vet. arhiv 49, 299-307.

Tabela 2. Pojava zaraznih bolesti domaćih životinja po pojedinim mjestima prema: Lukačević, J. (1989.): Stočne zarazne bolesti u Hrvatskoj u 18 stoljeću. VI. O učestalosti stočnih zaraza i tijeku 1776. do 1779. godine. Vet. arhiv 59, 41-48.

\begin{tabular}{|c|c|c|c|c|c|}
\hline Godina & $\begin{array}{c}\text { Županije/ } \\
\text { Krajine }\end{array}$ & Br. mjesta & Bolesnih & Uginulih & Uk. zaraženih \\
\hline 1776. & $\begin{array}{c}\text { Banska } \\
\text { krajina }\end{array}$ & 4 & 32 & 41 & 73 \\
\hline 1776. & Varažd. & 1 & - & 32 & 32 \\
1777. & Varažd. & 2 & 23 & 511 & 534 \\
\hline 1778. & Varažd. & 23 & 338 & 908 & 1246 \\
\hline 1779. & Varažd. & 1 & $?$ & - & \\
\hline 1777. & Križev. & 1 & 50 & 962 & 969 \\
\hline 1778. & Križev. & 1 & $?$ & & - \\
\hline 1778. & Virovit. & 5 & 7 & - & 2854 \\
\hline 1778. & Zagreb. & 1 & - & 2460 & \\
\hline 1778. & Slav. krajina & 1 & 450 & & \\
\hline
\end{tabular}


5. 5. 1877. broj $2355 .{ }^{54} \mathrm{U}$ Koprivnici se 1849. g. spominje živoder Lavoslav Stenreiter. U civilnoj Hrvatskoj 1850. g. predložen je Osnov za unaprjeđenje zdravičnog upraviteljstva, a 14. 6. 1850. g. na skupštini liječnika (na sjednici prisustvuje Maksim Smidt) u čl. 6, a predlaže se da se ustraje tražiti praktična učilišta za primalje i živino liječnike. Naredba za pomorsko zdravstvenu službu iz 1851. g. vrijedila je za primorje i Krajinu, a odnosila se na postupak sa životinjama i životinjskim sirovinama za vrijeme trajanja neke zarazne bolesti. U Koprivnici je 1852. g. guljar vjerojatno koža Lav. Ašcurcitor s plaćom od 25 forinti. Goveđa kuga pojavila se 1862. g. i 1863. g., a u Koprivnici je živoder 1863. g. Josip Šmidtlehner. Goveđa kuga zabilježena je u cijeloj Hrvatskoj 1864. g. kada je uginulo 5598, a pobijeno 249 grla goveda dok je u Vojnoj Krajini samo do kraja 1863. uginulo 2000 grla. Zemaljska pastuharna ustrojena je 1871. g., a 1872. g. goveđa kuga dijagnosticirana je u Kutjevu i virovitičkoj županiji, a te 1872.

54 Vučevac, V. (1979.): Povijest suzbijanja i sprječavanja stočnih zaraza u Hrvatskoj. Vet. arhiv 49, 299-307. g. nakon razvojačenja Vojne krajine zemaljska vlada u Zagrebu izdaje uputu kako se treba vladati pri stočnoj zarazi.

Zakon o uređenju zdravstva iz 1784. g. prvi put određuje status veterinarstva i njezina organizacija, a još je bilo u sastavu saniteta. Nije bila riješena organizacija suzbijanja zaraznih bolesti. Goveđa kuga u Hrvatskoj uočena je 1873. g., 1875. g., 1876. g., 1877. g. svinjska kuga, 1879. g. goveđa kuga. ${ }^{55}$ Goveđa kuga 1882. g. javlja se kao posljednja epizootija u Hrvatskoj iako se pojavila u Dalmaciji i banskoj Hrvatskoj u pojedinačnim slučajevima 1877. g. ${ }^{56}$ Zakon o uređenju veterinarstva propisuje suzbijanje ovih bolesti: goveđa kuga, bjesnoća, bedrenica, durina, spolni ospi konja, sakagija, slinavka i šap, plućna zaraza goveda, ovčje boginje, šuga konja i ovaca te vrbanac. Svinjska kuga pojavljuje se prvi puta u Slavoniji 1894. g., a 1895. g. pojavila se u području Gole i Ždale te se proširila se po cijeloj Hrvatskoj

\section{Brozović-rukopis}

56 Vučevac, V. (1979.): Povijest suzbijanja i sprječavanja stočnih zaraza u Hrvatskoj. Vet. arhiv 49, 299-307.

\section{Infectious domestic animal diseases in $18^{\text {th }}$ and $19^{\text {th }}$ century in the Croatian Banovina}

Petar DŽAJA, DVM, PhD, Full Professor, Faculty of Veterinary Medicine University of Zagreb, Croatia; Sonja SINKOVIĆ, DVM, Croatian Veterinary Institute, Zagreb, Croatia; Magdalena PALIĆ, DVM, Faculty of Veterinary Medicine University of Zagreb, Croatia; Josip MIHALJ, DVM, Veterinary Practice Soljani, Croatia; Krešimir SEVERIN, DVM, PhD, Full Professor, Faculty of Veterinary Medicine University of Zagreb, Croatia

This article presents the incidence and epidemiology of infectious domestic animal diseases in $18^{\text {th }}$ and $19^{\text {th }}$ century in the Croatian Banovina, included the predominant bovine plague. The first medical persons to recognize these infectious diseases and to perform necropsies of domestic animals to determine pathoanatomical changes and to give diagnoses are mentioned. Practitioners who controlled the infectious diseases of domestic animals and the obligations and measures to be ordered and implemented and the duties and obligations of animal owners during this period are outlined. During this period, diagnoses were given in Latin and German, with different terms that likely related to the bovine plague.

Key words: infectious diseases; century; domestic animals; Croatian Banovina 